\title{
FROM TONG-TONG TO TEMPO DOELOE: EURASIAN MEMORY WORK AND THE BRACKETING OF DUTCH COLONIAL HISTORY, 1957-1961
}

\section{Andrew Goss ${ }^{1}$}

In 1958, the Netherlands Institute for International Cultural Relations launched the magazine Delta, a review of Dutch culture. It was a typical cultural events magazine published with government money. Contemporary art, music, film, dance, fiction, and poetry were presented alongside laudatory reviews of Dutch cultural achievements. Its title, referring to the system of seawalls constructed after the 1953 flood, was a perfect metaphor for the famous technological prowess of the Low Countries. A map of the Netherlands was printed on the back cover. The message was clear: the Dutch, no less than the Americans or the French, were embracing a post-war spirit of democracy, science, and progress. But what is striking is that the writers treated the future with great caution. The question of how the Netherlands could play an important role in post-World War II Europe was answered with reference to the past. History was called on to explain past achievements and their possible development in the upcoming years. This history was especially needed to mend the tear Dutch culture had suffered during the 1940s. Military defeat and occupation by the Germans, political defeat by the Indonesian Republic, and the loss of empire, had severely shaken Dutch national confidence.

\footnotetext{
${ }^{1}$ I would like to thank Benedict Anderson, Pax Bobrow, Geoff Eley, Paige Shipman, and Ann Stoler for valuable comments and suggestions on earlier drafts.
} 


\section{Andrew Goss}

Delta took the issue of Dutch history seriously, and two contending explanations linking the heritage of pre-war culture with a prosperous future emerged in the journal. The prominent historians Pieter Geyl and Jan Romein, representing conservative and progressive politics respectively, summarized their post-war scholarship in a series of short articles. In one issue, speaking against the "prophecies of doom" which forecast the end of Western culture, Geyl argued that the events of the mid-twentieth centuryespecially the collective defeat of Hitler and the democratization of Europedemonstrated the vital universal spirit of western European culture. The difficult struggles of the early twentieth century, claimed Geyl, had been overcome by "a sense of responsibility for the whole of the community." Western civilization, still going strong, was defending the values of equality. ${ }^{2}$ In the following issue, Romein rebutted Geyl with the argument that history showed that during the seventeenth century European society diverged from the path it had followed in common with non-Western societies and began to function in a new and different way. This did not, however, imply that Europe was inherently superior. Different societies and cultures functioned with their own logic and validity. But attitudes towards time, nature, and life, which historically developed differently in western Europe, allowed Westerners to colonize Asia, Africa, and the Americas. Western culture's peculiarity was to instill "esteem for work for its own sake, even a conviction that work is holy." World history demonstrated that Western ideas about work, and European institutions such as capitalism, could be powerful vectors for changing non-European history. ${ }^{3}$

There is nothing peculiar to the late 1950s about these two viewpoints. Romein and Geyl had themselves worked out the core of their historical thinking in the early 1950s. Furthermore, these arguments, one advocating a belief in a superior Western civilization and the other offering a relativist approach to the world's past, reverberate in the Netherlands and elsewhere to this day. What is striking, however, is that both Geyl and Romein claimed that the history of European imperialism provided their best evidence for their respective understandings of Dutch history. Furthermore, both felt that their opponent's theories failed because of their flawed interpretation of the historical relationship between East and West. In an era of rapid decolonization, this issue was particularly critical for thinking about the future. In 1956, Romein wrote one of the first general historical accounts, in any language, of Asian nationalism. ${ }^{4}$ While European imperialism may have been its originary cause, he argued, twentieth-century nationalism in Asia had its own historical logic. Asian history should be studied on its own terms. Geyl mocked Romein for his Asiacentric approach and claimed that the superiority of Western civilization ruled out the necessity of studying Asia. For Geyl, everything good in Asia came from Europe. In effect, both historians upbraided each other for hubris: Romein showed Geyl to be Eurocentric and conservative, while Geyl accused Romein of engaging in nothing more than liberal guilt. 5

\footnotetext{
2 Pieter Geyl, "The Vitality of Western Civilization," Delta 2,1 (Spring 1959): 5-19.

3 J. M. Romein, "The Common Human Pattern," Delta 2,2 (Summer 1959): 5-19.

${ }^{4}$ An English translation was published in 1962: Jan Romein, The Asian Century: A History of Modern Nationalism in Asia (London: Allen \& Unwin, 1962).

${ }^{5}$ The styles of Geyl and Romein were quite different. Romein thought through the historicist philosophy of nineteenth-century Germany, whereas Geyl organized much of his post-war thought through criticisms of contemporary historiography. As a result, Geyl was a more vociferous critic of Romein than vice versa. For
} 
Romein's and Geyl's arguments are emblematic of the two post-war methods for approaching the Netherlands' place in the world. Romein, and other Asiacentric scholars, argued that, in Willem Wertheim's words, Indonesia and Asia "will discover that the only effective answer to the challenge from the West will be the assimilation of Western cultural factors in a manner adapted to the structure of Asian society." 6 In this scholarship, the agency of Asians, not Dutch colonials, was researched. On the other hand, Pieter Geyl and other historians of the Dutch golden age argued that "in us there lives the tradition of a great civilization."7 The origins of this tradition were to be found in European, and not Asian, history. But Romein's and Geyl's explanations shared one feature. While their contending arguments sought to explain the role of Dutch imperialism in world history, both were silent about the end of the Netherlands' reign as a world power in the 1940s. In the 1950s, most scholarship followed Delta in silently passing over the Dutch colonial experience in the Indies. ${ }^{8}$ From the standpoint of the 1950s, the colonization of Indonesia looked like a failure, and consequently meaningless for either Holland's future or its past.

How different it is today. Dutch colonial experience, a topic that was an embarrassment in the late 1950 s, is no longer buried in silence. Frances Gouda, in her book on twentieth-century Dutch colonial and post-colonial culture, has observed that "[i]n the course of rehearsing, revising, and retelling these stories, their perennially changing plots help to negotiate and accommodate a shifting national identity." ${ }^{\prime 9}$ Every form of colonial public memory exists: monuments, historical monographs, TV documentaries, memoirs, and novels. Recently arguments about the meaning of colonial history have been raised in parliament. In the last decade, the debate has probed the collective memory and consciousness of the Dutch nation during decolonization. ${ }^{10} \mathrm{As}$ Vincent Houben has argued, this debate, now almost thirty years old, has failed in the sense that the period 1945-49 is still shrouded by silence, and is denied and avoided by most of the Dutch public. ${ }^{11}$ Part of the tension that has driven this debate is caused by the paradox that although the decolonization of Indonesia has produced little serious soul-searching, the number of memoirs, photo-books, diaries, and histories of Dutch colonialism seem to double each year. Yet this nostalgic resurrection of empire is detrimental to the Dutch nation's ability to accept responsibility for the serious war crimes committed during the "police actions" of 1947 and 1948. In this sense, living memories of Indië are still a powerful force in shaping current Dutch national identity.

an early example, see Pieter Geyl, "Jan Romein, or Bowing to the Spirit of the Age," [1947] in Encounters in History (Cleveland, OH: Meridian Books, 1961), pp. 321-327. For a recent collection of essays about Romein's work, see Bert Hageraats, ed. Geloof niet wat geschiedschrijvers zeggen . . ‘. Honderd jaar Jan Romein, 1893-1993 (Amsterdam: IISG, 1995).

${ }^{6}$ W. F. Wertheim, Indonesian Society in Transition: a Study of Social Change, 2nd ed. (The Hague: W. van Hoeve, 1964), p. 336-7.

7 Geyl, "The Vitality of Western Civilization," p. 13.

${ }^{8}$ The journal Indonesië, which did carry such discussions, ceased publication in 1952.

${ }^{9}$ Frances Gouda, Dutch Culture Overseas: Colonial Practice in the Netherlands-Indies, 1900-1942 (Amsterdam: Amsterdam University Press, 1995), p. 241.

${ }^{10}$ Remco Meijer, ed., Oost indisch doof: Het Nederlandse debat over de dekolonisatie van Indonesië (Amsterdam: Bert Bakker, 1995).

11 Vincent J. H. Houben, "A Torn Soul: The Dutch Public Discussion on the Colonial Past in 1995," Indonesia 64 (October 1997): 47-66. 
12 Andrew Goss

Where did these memories come from? Contemporary observers of the colonization and decolonization of Indonesia have generally shared the belief that discussion of Tempo Doeloe ("the good old days"), in one form or another, has always been a component of the Dutch narrative of their imperial history. They have assumed that Tempo Doeloe is the logical post-war continuation of the Dutch "civilizing mission." But in fact, between 1950 and 1958 colonial history was not discussed at all. For Geyl and Romein, and for most other public intellectuals, it was a source of embarrassment. These intellectuals and politicians believed that Indonesia's decolonization and its effects could be ignored. As a corollary, they believed that Dutch citizens who emigrated from Indonesia in the 1950s, many of whom had never before been to the Netherlands, could be smoothly acculturated into a Dutch nation that ignored its colonial history. This paper will argue that it was only after Dutch culture passed through a crisis in 1958, when suddenly boatloads of Eurasian repatriates streamed into the Netherlands, that a space opened up for a strange recuperation of Dutch colonial culture. Initially, a small political movement spearheaded by the Eurasian writer Tjalie Robinson sought to recreate the colonial lifestyle of the Indies in the Netherlands. The consequence of this highly visible, though doomed, social movement of Eurasians was not political power, but, instead, the creation of Tempo Doeloe. Since the early 1960s, the history of the Netherlands East Indies has again been part of Dutch culture, but bracketed within the main narrative of Dutch history and attached primarily to the living memories of ex-colonials in the Netherlands.

\section{Verzuiling}

After the second World War, most Dutch politicians and intellectuals were, like Geyl and Romein, interested in rebuilding the national identity. ${ }^{12}$ After two decades of blows to the country's social and economic order-the Depression, Nazi occupation, loss of empire-the future looked bleak once the euphoria of Allied liberation had worn off. The economy was bankrupt, and the public's confidence in the "Dutch way of life" was severely shaken. Every year, tens of thousands of citizens emigrated to Canada, South Africa, New Zealand, and Australia. In 1946, an unlikely political coalition between the Catholic Party and the Labor Party won control of the national government. Despite the financial difficulties, and the humiliating loss of the Indies, this coalition lasted until 1959 and presided over a time of surprising economic progress and social peace. By 1952, after the infusion of Marshall plan money, the Dutch nation had established itself as largely independent and prosperous. European unity, enthusiastically supported by most Dutch, promised a militarily secure future. ${ }^{13}$

\footnotetext{
12 Driven largely by increased industrialization and aggressive export policies, the economy grew steadily, and between 1950 and 1960 the real gross national product increased an average of 4.9 percent per year. This was exceptionally high compared to pre-war growth; between 1922 and 1938, the real GNP only grew an average of 2.1 percent per year. F. Messing, "Het economische leven in Nederland 1945-1980," in J. C. Boogman et al., Geschiedenis van het moderne Nederland: Politieke, economische en sociale ontwikkelingen (Houten: De Haan, 1988), p. 535.

13 J. J. Woltjer, Recent Verleden: De Geschiedenis van Nederland in de Twintigste Eeuw (Amsterdam: Balans, 1992), pp. 233-257.
} 
It was in this same decade that a view of the nation as naturally divided between religious groupings, on the one hand, and ideological communities, on the other, crystallized in both the parliamentary and scholarly spheres. The nature of the political system structured by these ideological cleavages was initially and sarcastically labeled verzuiling ["pillarization"] by its critics, but soon all political commentators came to use the architectural metaphor to describe Dutch society. ${ }^{14}$ In this model, a few sturdy pillars, representing different vertical segments of society, stood separately, but side by side, supporting the house of Dutch democracy. Only the Catholics made up a true vertical pillar, in the sense that they formed a bloc that included members from all classes. The other communities, such as the reformed Protestants, orthodox Protestants, liberals, and socialists, while not as vertically homogeneous, made up quasi-pillars. To the sociologists and politicians attached to the ruling parties in the 1950s, verzuiling made sense out of the post-war political coalition between the Catholic party and the socialist party, an alliance deemed unlikely before the war. This coalition favored strong welfare statist policies and had a vested interest in theorizing the relationship between Dutch society and democracy. Before the war, the ruling rightwing coalition-one part of which collaborated with the Nazi occupying forces-had little use for progressive theories about state and society relationships. Verzuiling, and its associated progressive policies, was a way to move beyond the pre-war conservative leadership and the collaborationist era of 19411945. ${ }^{15}$ While socially the Dutch citizenry remained divided-those most committed to religious traditions rarely interacted with confirmed socialists-their leaders worked together to ensure the future of the democracy through compromise and accommodation.

Verzuiling was a highly effective tool for politicians eager to rationalize the political coalition between Socialists and Catholics, and for sociologists who wished to interpret and manage Dutch society during the 1950s. But it quickly became something more. Verzuiling became the perfect esteem-building explanation for understanding Holland's uniquely Dutch transition to modernity. "External" influences, such as the Depression, World Wars I and II, the Cold War, and the colonial empire, were glossed over in favor of the national logic of modern Dutch history. According to this way of thinking, the destiny and unity of the nation were purely the result of compromises between its domestic modern and traditional pillars. Verzuiling quickly became the organizing principle for the history of "Little" Holland after 1880. Historical happenings outside the scope of this "history of our modernization"-most importantly the collapse of a huge, ancient colonial empire-were conveniently erased. This modernizing story became so important that some influential social theorists felt

\footnotetext{
14 The easiest way to approach Dutch pillarization in the English language is through Arend Lijphart, The Politics of Accommodation: Pluralism and Democracy in the Netherlands (Berkeley: University of California Press, 1968). This influential book, which has been translated into Dutch, grapples with comprehending the stability of the Dutch democracy in spite of its deep cutting cleavages. Lijphart looks especially to the cooperation between the Dutch elites on a parliamentary level, and their ability to mitigate potentially volatile disagreements. Inspired primarily by the Dutch case, he creates a model of what he calls a "consociational" type of democracy in countries with fragmented political cultures but simultaneously compromising elite behavior. For an elucidation see Lijphart, "Typologies of Democratic Systems," Comparative Political Studies 1,1 (April 1968): 3-44, and Lijphart, Democracy in Plural Societies: $a$ comparative exploration (New Haven: Yale University Press, 1977).

$15 \mathrm{I}$ am indebted to Benedict Anderson for this point.
} 
14 Andrew Goss

that immigrants could only adapt to the "Dutch way of life" if they found a place in one of the existing pillars. This theoretical socialization process came first to be applied to the colonial repatriates from the Netherlands East Indies.

\section{The Repatriates}

Between 1945 and 1960, three hundred thousand people of Dutch nationality came to Holland from the Indies. About one-third of these so-called repatriates were veterans of the 1945-1949 war against the Indonesian Republic. Another third was made up of totoks, or colonials who had been born in Europe. Approximately one hundred thousand repatriates, however, had never before lived in the Netherlands. As these repatriates arrived, they were all carefully monitored and categorized by Dutch social workers. A variety of commissions, organizations, and agencies were formed to aid, classify, and study their entry into the Netherlands. These organizations were especially concerned about the repatriates who were racially Eurasian-in Dutch they were called Indo-Europeans or Indos. ${ }^{16} \mathrm{~A}$ smooth integration of these Eurasians into post-war Dutch society would prove the efficacy of the verzuiling system reconciling the tradition and modern segments. But in the Dutch government, there was a worry that these Indo-Europeans might have trouble fitting in. Were they really Dutch, after all? Unlike other colonial powers, the Dutch colonial state had never created a distinct legal status for Eurasians. A Eurasian child was either Dutch (if acknowledged and officially registered by his or her Dutch father) or native (if not so registered). "Dutch" Eurasians tended to cling to their Dutchness, even as their real socio-economic situation went into steep decline after the massive influx of "pure Dutch" to the Indies from the 1870s on. They were loyal to Holland and the empire, but they were poor in the Indies and nearly destitute on arrival in Holland. Furthermore, in the Indies and in Holland itself, many people considered all Eurasians, whether legally Dutch or native, to be the embodiment of European degeneration in the tropics. ${ }^{17}$ This explains why the bulk of a literature ostensibly about repatriates in general was most deeply concerned with strategies for coping with this "degenerate" population. The studies generally found that pure-blood Dutch "repatriates" had no big problem in adapting to a pillarized society-with the possible exception of occasional inferiority complexesand little research was wasted on them. It was "Dutch" Eurasians, a growing problem for the colonial state since at least the 1870 s, who became a test-case for the capacity of a "uniquely Dutch" verzuiling system.

Virtually no poor Eurasians had lived in the Netherlands before 1945. Although Eurasians in general had a role in the myths about the colony that circulated through Holland, this population was of little relevance, either politically or socially, to the domestic concerns in the mother country. Thus, when large numbers of poor Eurasians entered Holland after World War II, the Dutch authorities were not well prepared. Government committees and organizations were established to classify, monitor, and

\footnotetext{
16 The classic definition is found in Willem Wertheim, Het Rassenprobleem, De ondergang van een mythe (Den Haag: Albani, 1949).

17 Ann Stoler, "Sexual Affronts and Racial Frontiers: European Identities and the Cultural Politics of Exclusion in Colonial Southeast Asia," Comparative Studies in Society and History 34,2 (July 1992): 515.
} 
help the repatriates. The cross-verzuiling CCKP (Central Comite van Kerkelijke en Particulier Initiatief voor sociale zorg aan gerepatrieerden, or Central Committee of Religious and Private Initiatives for the Social Care for Repatriates), established in 1950, handled the repatriates' immediate needs upon arrival. ${ }^{18} \mathrm{~A}$ Dutch social worker from the CCKP, assigned from the pillar deemed appropriate, greeted the repatriate when he or she stepped off the boat and facilitated the new arrival's settlement in temporary hostels. These contact persons continued to monitor the repatriates, especially the poorer ones, for a number of years, until they were safely settled into society.

The CCKP comprised an impressive twenty organizations and ranged across all pillars, blocks, and classes. The first chair of the CCKP went as far as to say in 1951, that this complete representation within a single national organization was unique:

In this country of sectarianism and separatism a commission was formed in which the three famous "pillars" of the Netherlands did not just find and support each other, but continuously worked together harmoniously. . . . It can rightfully be said that the entire Dutch nation is represented in the CCKP. [emphasis his] ${ }^{19}$

This was quite logical: in a time of crisis, diverse and sometimes antithetical organizations pool their resources and forget their differences; to facilitate the smooth absorption of the repatriates, the elites of the various pillars would forge compromises and join together for the national good. But this statement does not merely indicate cooperation between disparate groups. Projecting society as pillarized allowed the head of the CCKP to ignore the differences and cleavages within the Netherlands and focus rather on the totality of what it meant to be Dutch. With "Dutch" Eurasians streaming into the Netherlands, the Dutch faced the task of trying to absorb a population that did not fit into society, either politically or culturally. They were determined to do so; the repatriates would have little to say about their situation. In a nation united by verzuiling, Eurasians had no place for their own traditions.

Thus, during the 1950s, the Eurasians were generally kept out of the national spotlight, with one notable exception. They did attract Dutch attention when they came to play a role in the West New Guinea dispute. The most serious and long-lasting post-imperial altercation between the leaders in Jakarta and The Hague concerned the "return" of West New Guinea-known then in Indonesia as Irian Barat-to the Indonesian nation. President Sukarno argued that West New Guinea lawfully, historically, and logically belonged to Indonesia. According to The Hague Agreement of 1949 , the future of the area was to be decided by subsequent talks between Indonesia and the Netherlands. But the Dutch broke off talks in the early 1950s and maintained sovereignty over West New Guinea. Because West New Guinea was economically a liability to the Dutch, unlikely to be productive or to offer any strategic advantages, the famed political scientist Arend Lijphart concluded that only subjective and psychological factors could explain the tenacity the Netherlands showed in holding on

18 See H. C. Wassenaar-Jellesma, Van Oost naar West ('s-Gravenhage: Staatsuitgeverij, 1969), pp. 29-33, for a history of the CCKP.

${ }^{19}$ Quoted in ibid., p. 210. For the list of the twenty organizations represented in the CCKP, see ibid., pp. 200-201. 


\section{Andrew Goss}

to this territory. ${ }^{20}$ But one should note that, well before 1949 , nationalist groups in the Netherlands had worked to convince the Dutch government to keep West New Guinea as a possible homeland for "Dutch" Eurasians. These nationalists, some of whom were Eurasians themselves, now used the resettlement scheme as a reason for holding onto a vestige of the old Dutch empire. In 1949, as Dutch colonial authority crumbled, "Dutch" Eurasians living in Indonesia were generally enthusiastic about the plan, and, in the following year, 8,500 Dutch people, mostly Eurasians, actually settled in West New Guinea. ${ }^{21}$ But this rugged country was nothing like Java, and enthusiasm quickly waned. After 1950, very few Eurasians moved to the area, and many of the initial colonists moved back to Java or went to Europe. But even after the resettlement plan failed in practice, a number of conservative interest groups in the Netherlands continued to cite the plan as a reason for retaining West New Guinea. These groupsand they argued bitterly amongst themselves-wielded little influence over Eurasians living in Holland, however, because they remained tied to the unpopular and obsolete program of resettlement. They were never able to unify the Dutch "Eurasian" population politically.

\section{Eurasians in the Spotlight}

The arrival and dispersal of the Eurasian repatriates in Holland sparked certain individuals to recall, at least privately, the colonial stereotype of these "marginal" Europeans from Asia. One police agent in The Hague was reported as saying:

There are and will come enough other difficulties with these Eastern people. East is East and West is West. And especially these Indo-Europeans, born in sin, with their bad background, will have a difficult, nearly impossible job adapting themselves to the Dutch morals. ${ }^{22}$

Aware of these prejudices (and perhaps sharing a number of them), the government understood that gaining a stable livelihood would constitute only one of the many challenges confronting the refugees as they sought full assimilation into Dutch society. In order to gauge the success of its "integration programs," the state needed expert research on the social adaptation of the Eurasians. This research, commissioned in 1954 by the Minister for Social Work, was intended to supplement the efforts of the CCKP by tracking the "social integration of the people repatriated from Indonesia." 23 The research team, representing the Protestant, Catholic, and socialist pillars, was comprised of sociologists from the Dutch Institute of Social Research, the Sociological Institute of the Dutch Reformed Church, and the Catholic-Church Social Institute. Their

\footnotetext{
20 Arend Lijphart, The Trauma of Decolonization: The Dutch and West New Guinea (New Haven: Yale University Press, 1966), p. 66.

21 Ibid., p. 131.

22 Quoted in Topaas de Boer-Lasschuyt, "Eurasian Repatriates in Holland," R.E.M.P. Bulletin 13,2 (1959): 25 . The belief that miscegenation was sinful and produced inferior children was a common colonial stereotype.

23 J. H. Kraak, ed., De repatrieering uit Indonesië: Een onderzoek naar de integratie van de gerepatrieerden uit Indonesie in de Nederlandse samenleving (The Hague: Instituut voor Sociaal Onderzoek van het Nederlandse Volk, 1958), p. 7.
} 
work was overseen by J. P. Kruijt, one of the most important verzuiling sociologists in the country.

The commission's mandate was to evaluate how smoothly the repatriates, but especially the Eurasians, were being integrated into Dutch society. The initial assumptions of the commission, based primarily on conclusions about Eurasians which had long been in circulation in the colonies and sketched out in the first thirty pages of the 450 page report, anchored the sociological data collected in 1955 to colonial antecedents. In the process, the Dutch state thereby reproduced some of the mindset of the expired colonial state. The historical section of the report argued that the Eurasians, although importantly European in many ways, had not benefited from constant contact with modern European culture; what's more, they had assimilated a number of local Indonesian values. But the reporters were nonetheless optimistic. They concluded that, in spite of the Eurasians' disadvantages, chances were good that the Eurasians would succeed in coping with a post-World War II Europe because at bottom they were European in outlook and values. ${ }^{24}$

The bulk of the report, De repatrieering uit Indonesië, studied the contemporary problems of integration. After recounting the many reasons that had motivated people to repatriate, reporters then described the process of their re-socialization in detail. Based on interviews and surveys, the report analyzed the success or failure of individuals to adjust to the practical aspects of Dutch life, to participate in Dutch society, and to feel personally satisfied. Further chapters covered the repatriates' adjustment to work, housing, family life, and church. Three general conclusions were drawn: the repatriates were well adjusted to the logistical and practical aspects of life in Holland; they maintained few personal contacts with non-repatriated Dutch; and although they felt their current life was less than optimal, many foresaw a positive future. ${ }^{25}$ These results are unsurprising in some aspects. After the violent and difficult 1940s, and the disappointing early 1950s, the repatriates were only slowly able and willing to adjust to their new environment, but a majority of those polled maintained positive attitudes about the prospect of adjusting to their new surroundings. Their "realistic acceptance of the actual situation" and "adjustment of aspirations" set them apart from a small minority who had "strong feelings against Dutch society." 26 Since more than half the people surveyed showed positive attitudes toward adjustment, the authors of the report were optimistic that, with time, more repatriates would positively adopt their new homeland.

By measuring individuals' positions on an adjustment-attitude scale, the reporters aimed to gauge the process of normalization. How successful had the force of pillarization been? Could the Eurasians find a place in an established pillar? Although in many cases the answer seemed to be "no," 27 the sociologists continued to show

\footnotetext{
24 This was most clearly formulated as follows: "The culture of these groups [the Eurasians] was then one of a Dutch lifestyle adjusted to the Indonesian milieu, rather than a Dutch-influenced, Indonesian lifestyle." Ibid., p. 63.

25 Ibid., p. 378.

26 Ibid., p. 377.

${ }^{27}$ For example, the chapter studying the integration into the confessional pillars found that most repatriates were spiritually not attached to a church. For the report writers, this was no cause for immediate alarm, since the repatriates could still belong to either the socialist or liberal pillars.
} 


\section{Andrew Goss}

confidence in the logic of Dutch modernization as it was expressed through pillarization. They decided that as long as repatriates maintained an attitude toward adjustment that was generally positive, the provision of adequate housing, food, and work would ensure that assimilation would progress steadily. Even though for the moment pillarization seemed to be an inadequate tool for understanding the Eurasian immigrants, the report's authors felt time would show its efficacy.

Subsequent studies of the repatriates' entry into Dutch society have confirmed these authors' predictions. ${ }^{28}$ Although these later studies dropped pillarization as an organizing principle, they did validate much of the optimism of Kruijt and his team. Many of the Eurasians who came over as adults were indeed never able to feel "at home" in the Netherlands, but their children did. Neither the Dutch nor the repatriates resorted to violence. The Dutch public was aware of, and sympathetic to, the repatriates' plight. In hindsight, all went well. But at the time that De repatrieering uit Indonesië was being composed, with most of the hope pinned on pillarization, it was not clear that assimilation would proceed smoothly. In the middle of the 1950s, public silence about the colonial past predominated. But, as the events of early 1958 showed, real assimilation would require public acknowledgment of the Indies as a component of Dutch history.

\section{The Final Wave of Repatriation}

During 1957, heightened tensions over West New Guinea brought Indonesia and the Netherlands close to war. Indonesia had been unable to convince the UN to intervene in the West New Guinea dispute, and Holland was ignoring everything Indonesia said or did. As a result, the Indonesian government called for a general boycott of Dutch businesses on December 1, 1957. Four days later, the Indonesian Minister of Justice announced that all non-essential Dutch nationals would be repatriated to the Netherlands. ${ }^{29}$ This announcement started a hasty exodus of thousands, including

28 J. E. Ellemers and R. E. F. Vaillant, Indische Nederlanders en Gerepatrieerden (Muiderberg: Dick Coutinho, 1985), p. 10, hail this report as the most important source about the colonial repatriates. The Ellemers and Vaillant book updates the Eurasian scholarship to the early 1980s and concentrates on the socio-economic position of the repatriates in the Netherlands after the 1950s. For earlier studies, see J. Ex, Adjustment after Integration: A longitudinal study of the process of adjustment by refugees to a new environment (The Hague: Martinus Nijhoff, 1966); H. G. Surie, "De gerepatrieerden," in Allochtonen in Nederland, ed. H. Verwey-Jonker ('s-Gravenhage: Staatsuitgeverij, 1971), pp. 45-108; Christopher Bagley, The Dutch Plural Society: A Comparative Study in Race Relations (London: Oxford University Press, 1973); J. M. M. van Amersfoort, Immigratie en minderheidsvorming: Een analyse van de Nederlandse situatie 19451973 (Alphen a/d Rijn: Samson, 1974).

${ }^{29}$ Leslie Palmier, Indonesia and the Dutch (London: Oxford University Press, 1962), pp. 103-105. In the transition Sukarno made from Constitutional Democracy to Guided Democracy in 1957 and 1958, he benefitted from scapegoating the Dutch ex-colonials. For Indonesian politics during the 1950s, see Herbert Feith, The Decline of Constitutional Democracy in Indonesia (Ithaca: Cornell University Press, 1960) and Daniel S. Lev, The Transition to Guided Democracy: Indonesian Politics, 1957-1959 (Ithaca: Cornell University Southeast Asia Program, 1966). For a contemporary, and more Dutch, view of Indonesian socioeconomic conditions, see B. H. M. Vlekke, ed., Indonesia's Struggle 1957-1958 (The Hague: Netherlands Institute of Internal Affairs, 1959). 
many poorer Eurasians. ${ }^{30}$ By September 1958 the last repatriate had left Indonesia; a total of approximately thirty-five thousand Dutch citizens had entered the Netherlands since the expulsions began the previous December.

As a result of these dramatic expulsions, a clamorous debate about the repatriates broke out in the Netherlands. Till then, while some of the Dutch public surely noticed foreign-looking people living next door, riding the same bus, or attending school with their children, the Eurasians largely stayed out of the newspapers. Now the public had to face the reality that the expulsion of the Dutch citizens was a political act, whereby the Eurasian population was made to pay for the Dutch government's failure to find an adequate solution to the West New Guinea crisis. Vivid reports, with photographs, of the repatriates' departures, journeys, and arrivals were printed on the front pages of most daily newspapers. The Eurasians were generally depicted as the innocent victims of the difficult process of decolonization in Indonesia. Although the actual number of repatriates in 1958 was only double the number originally expected, ${ }^{31}$ the circumstances of their arrival attracted far more national attention than had occurred over the seven previous years, since the transfer of sovereignty to Indonesia. ${ }^{32}$ Because of the suddenness of Indonesia's actions, the government's organizations could no longer handle the situation alone and were forced to rely on the cooperation of the citizenry. Hence the leaders of Dutch society were compelled to advise the public on their responsibilities to these "long lost children."

The logistical and emotional difficulties of absorbing an additional twenty or thirty thousand homeless Eurasians into Dutch society were quite daunting. These Dutch citizens, who had tenaciously stayed on in Indonesia after the transfer of sovereignty, were described as psychologically the farthest removed from Holland and, therefore, the hardest to integrate. ${ }^{33}$ With no time for planning, the repatriates, sometimes carrying only two suitcases of possessions, were literally being dropped off at the docks in Amsterdam and Rotterdam. In this stressful time-stressful both for the individuals arriving by boat and for the Dutch nation in general-the newspapers and authorities preached optimism and understanding. On January 14, 1958, the Nieuwe Rotterdamse Courant published a front-page editorial entreating its readers to smooth the way for the repatriates so that they might speedily integrate themselves into Dutch society. It stressed that this effort would be beneficial to all, since "no community is served by the cultivation of a minority group that cannot find harmony with its surroundings and whose members start to feel locked out of society.... It is our moral duty especially to help the elderly." 34 News on the progress and arrival of large ships

\footnotetext{
${ }^{30}$ Under colonial rule, Eurasians were categorized as "Europeans" if they were officially claimed by their European father. After Indonesian independence, all legally classified Europeans were given the choice between Dutch and Indonesian citizenship. Some chose Indonesian citizenship, but many Eurasians chose Dutch citizenship even while remaining in Indonesia.

31 "Nederland bereidt zich voor op ontvangst van repatrierenden," Nieuwe Rotterdamse Courant, December $14,1957$.

32 In their survey of the Dutch press, Annemarie Cottaar and Wim Willems, Indische Nederlanders: een onderzoek naar beeldvorming ('s-Gravenhage: Moesson, 1984), p. 105, found 295 articles written in thirtyfive different Dutch newspapers about the Indisch Dutch; almost all of these articles were written in December 1957 and January and February 1958.

33 "Begrip gevraagd," Nieuwe Rotterdamse Courant, January 14, 1958.

${ }^{34} \mathrm{Ibid}$.
} 
was reported periodically, and photographs of smiling repatriates stepping off the boat from Indonesia appeared a number of times on the front pages.

The Nieuwe Rotterdamse Courant photographs-four were published during January 1958-are of special interest, because in all four pictures the repatriates shared the space with Queen Juliana. ${ }^{35}$ Since the queen was then the most potent symbol of Dutch national unity, 36 these pictures depicted, through metonymic use of the royal image, a country pleased to receive its long lost children back into the fold. ${ }^{37}$ A later photograph showed the Queen even welcoming repatriates into her palace. ${ }^{38}$ Not coincidentally, it was at this time that the CCKP asked Dutch householders to consider offering their spare rooms as temporary shelters for the refugees. Throughout the three-month crisis, the newspapers, the authorities overseeing the repatriates, and the Queen herself appeared to assume resolutely their leadership responsibilities and, through their impeccable examples, helped facilitate the transformation of the repatriates into post-war Dutch. It was noticeable, however, that while the smooth integration of the Eurasians remained a top priority, few policy makers and social theorists expected the silent force of pillarization to accomplish the job. Integration would now require everyone's active help.

Exactly one year after the appearance of De repatrieering uit Indonesie, the sociologist Topaas de Boer-Lasschuyt published the results of her field research on Eurasian assimilation up to the middle of 1958. Her findings and advice demonstrate a radical change in (some) Dutch people's perception of the Eurasians. The latter were no longer merely faceless and benign. She opposed forcefully integrating the Eurasians into a pillarized society, arguing that the wide cultural gap between the Eurasians and the Dutch could never be fully bridged, and the former would always stand outside Dutch society. De Boer-Lasschuyt advocated a policy that recognized the IndoEuropeans as a distinctive group with positive qualities benefiting Dutch society. Current policy, as promulgated in De repatrieering uit Indonesië, could only lead to feigned integration. Future policy and attitudes needed to show a "conscious acceptance of essential differences." 39 Her conclusion stressed not only the fundamental differences of philosophy, mentality, and temperament between the IndoEuropeans and the Dutch, but also the generally unfriendly attitude of the Dutch public towards the immigrants. The evidence marshaled for these conclusions was extensive and varied. De Boer-Lasschuyt noted the inability of the repatriates to fit into the tight corset required by a pillarized society, ${ }^{40}$ riots between Dutch and

35 See the Nieuwe Rotterdamse Courant, January 10, 1958; January 20, 1958; January 21, 1958; January 28 , 1958.

36 Arend Lijphart, The Politics of Accommodation, pp. 82-83.

${ }^{37}$ None of the photographs depicts adult men. Three of the photos show the queen chatting casually to a mother holding her children, while the last photograph shows three elderly women shaking hands with the queen.

38 Nieuwe Rotterdamse Courant, February 11, 1958. The caption below the photo reads: "Yesterday more than 60 evacuees from Indonesia moved into a section of the Loo palace in Apeldoorn. The children soon felt at home in the large halls."

39 De Boer-Lasschuyt, "Eurasian Repatriates in Holland," pp. 42-43.

40 Ibid., p. 36. 
Eurasian youths in The Hague in June of 1958,41 and the persistence of the longstanding image of the Eurasians as degenerates. ${ }^{42}$ The tensions between what the government advocated-the quickest possible integration of the repatriates-and what the man on the street thought-that the Eurasians were essentially different from the Dutch-would plague the nation for generations. According to de Boer-Lasschuyt, the most serious social cleavage in the Netherlands was the one that split the Eurasians from the Dutch; it was no longer, as pillarization theory contended, the cleavage dividing Protestants, Catholics, and socialists from one another. The gap between what she called the official "Dutch Creed"-the conviction that the Dutch were hospitable towards oppressed aliens and the belief that racial prejudice did not exist in the Netherlands-and the average citizen's comparatively intolerant attitudes towards "aliens" could only be bridged by an acceptance of basic differences. ${ }^{43}$ Unity-and she was skeptical that it could be attained soon-would only come through cross-racial understanding and acceptance.

De Boer-Lasschuyt also showed that the arrival of Eurasians from the Indies brought a new source of instability to Dutch national unity. They were tainted not just by their brown skins, but also by their ability to bring back a forgotten time. She described the problem as follows:

This frustration [after the loss of sovereignty] has caused two extreme ways of thought in Holland, (a) a feeling of guilt for the fact that Holland once was a colonial power with all the immoral consequences thereof, (b) a feeling of complete reaction-a wishing and longing for the return to the good old times which with a few alterations and harmless modernization, would offer a far better solution [both] for the Dutch and for the "natives." Since the final handing over of the Sovereignty to Indonesia supporters of both extremes have one trait in common: they dislike to be remembered [sic] of the colonial past. This is one of the difficulties Repatriates and especially the Eurasian Repatriates are faced with in Holland. 44

In 1958, and for the first time during the 1950s, the meaning of the colonial experience was being publicly addressed. Writers such as de Boer-Lasschuyt were now asking the nation to atone for the transgressions of colonial rule. The nineteenth- and twentiethcentury colonial mission had not just awakened the native Indonesians to the modern world, but had left a legacy of brown-skinned quasi-Dutch people; and these people had in many cases been cast off by the same Dutch who procreated them.

As a result, 1958 triggered a wave of guilt over hitherto unacknowledged aspects of the flawed colonial "civilizing mission." Paradoxically, the guilt and nostalgia surrounding the Indos opened up the possibility for Dutch history to be rewritten with serious reference to the Indies. Before then, historians such as Geyl and Romein treated colonial history as if it were of no relevance to the future of the Dutch nation. The repatriation emergency changed all this. The foreign looking Dutchmen and Dutch women were now to be welcomed back as children of the nation and to be promised a

\footnotetext{
41 Ibid., p. 24.

42 Ibid., p. 41.

43 Ibid., pp. 43-44.

$44 \mathrm{Ibid}$., p. 30. This article was originally written in English.
} 
22 Andrew Goss

real future in the Netherlands. It became clear that the Dutch nation needed to include an ex-colonial Indisch ${ }^{45}$ element. The question was, of course, on whose terms.

\section{Starting to Remember Indië}

The transformation from repatriate to Dutch, initially advocated by the authorities, necessitated that Eurasians jettison their traditions, culture, and lifestyles. The government, newspapers, and sociologists had insisted that the repatriates' heritage be replaced with Dutch traditions. The pressure to adapt to all things Dutch, applied officially even before disembarkation from the transport ships, convinced many repatriates that in adopting a new life in Holland, it was necessary to shed the colonial values of the Indies, at least in public. The official pressure to conform, which came from above, was combined with disrespect and discrimination from neighbors and coworkers. On the street, in the tram, and at work, Dutch citizens ignorant of the circumstances surrounding the repatriates' flight to the Netherlands stereotyped them as foreign freeloaders inimical to Dutch society. The Eurasians were subjected to racial slurs, prejudices, and humiliation. The simple physical difficulties they faced when trying to adapt to the new weather, temporary housing, and strange food were exacerbated by the unwillingness of most Dutch to respect or understand their situation.

Demonstrating competence over and over again. And working, and being brave, and trying hard, and being polite to the Dutch, whatever they called you. On the street, for example: "Hey, your underwear is showing," if you were wearing a sarong. Others said: "You blacks [zwartjes], go back to Sukarno." It became exasperating to explain that you were against Sukarno and that you weren't an Indonesian, but Indisch. You stopped explaining, and gathered only with other Indisch people, who understood you. You didn't talk about the sadness: not about the camps, not about the political actions, not about the many dead that you had seen, not about the Indonesian citizens whom you had to shoot as a colonial soldier, not about the friends whom you had seen bayoneted by the Japanese. You came from a culture of shyness. ${ }^{46}$

For most of the 1950s then, any public recollection of the former Dutch colonial society was frowned upon. ${ }^{47}$ Indonesia was a hated subject avoided by all. Only within the

\footnotetext{
45 This is a difficult word to pin down. Winniefred Anthonio, "Tjalie Robinson: 'Reflections in a Brown Eye,"' (PhD dissertation, University of Michigan, 1990), p. 5, defines it as follows: "Indisch is the Dutch adjective from Indië, the colloquial for Nederlands Indië. The meaning of this word is deeply rooted in the colonial context. Indisch means not Dutch, but for Indos it also means not Indonesian. It alludes to the culture of the Eurasians in the former colonies, which was marginal, leaning more to the indigenous culture than the Dutch among the poor and uneducated, but more to the Dutch the more one belonged to the well-todo. There were so many forms of 'Indischness' not only depending on education and social status but also on geographical location." In the post-war Netherlands, Indisch came to refer to the ex-colonials emotionally still connected to the Netherlands East Indies.

46 Tessel Pollman and Ingrid Harms, In Nederland door Omstandigheden (Baarn: Ambo, 1987), p. 30.

${ }^{47}$ Even at Leiden University, the site of a century of Orientalist interest in Indonesia, few students studied colonial history in the 1950s. See C. Fasseur, De Indologen, Ambtenaren voor de Oost (1825-1950)

(Amsterdam: Bert Bakker, 1994), pp. 472-473.
} 
confines of the private homes of fellow Indisch people could the repatriates feel free to tell their stories.

At first, the only public manifestation of colonial recollections came from individual and fictional voices. Following repatriation, a number of writers wrote fictionalized accounts of their youth in a dreamy Indisch past. All these accounts were intensely personal, grappling with individual experiences in the lost colonial order. Oeroeg, by Hella Haasse, published in 1948, may have been the first. This short novel is explicitly a memory exercise retracing the narrator's childhood with his friend Oeroeg, an Indonesian boy. Youthful adventures on a plantation in West Java form the core of the story of two boys, from different races and classes, who grew up as close friends. But the Japanese invasion divided them geographically, and the revolution ideologically. In a final, fantastical meeting, Oeroeg and the narrator are reunited on the shore of a lake in West Java. But communication between the Indonesian nationalist guerrilla and the now middle-class Dutch adult fails. After the Japanese Occupation and the Indonesian revolution, the youthful friendship cannot be rekindled. It can only be remembered. In the final paragraph of the book, the narrator, and by extension the author, explains the reason for the whole exercise.

I wanted nothing else than to simply write down an account of our shared youth. I wanted to anchor the image of those years, now passed without a trace as if they had been no more than smoke in the wind. Kebon Djati [the plantation on West Java] is a memory. ${ }^{48}$

For the author, the retelling and remembering succeeded in stabilizing the image of her youth, and she did not write again about the colonies for the next twenty years. She went on to have a successful career writing historical novels about medieval Europe. ${ }^{49}$ Following Hella Haasse's novella, came Maria Dermoût's Nog Pas Gisteren (Just Yesterday) in 1951,50 A. Alberts's De Eilanden (The Islands) in 1952,51 E. Breton de Nijs's Vergeelde Portretten (Yellowed Portraits) in 1954,52 and Maria Dermoût's classic De Tienduizend Dingen (The Ten Thousand Things) in $1955 .{ }^{53}$ None is a novel in a technical sense; they are series of short stories, really vignettes, with a great emphasis on characters coming of age in a colonial milieu. In many ways these novels fit into the canon of Dutch colonial literature stretching back to the seventeenth century. ${ }^{54}$ The

48 Hella Haasse, Oeroeg (Amsterdam: Querido, 1948), pp. 127-128.

49 She did, however, come back to the colonies. In addition to various autobiographical texts, she wrote the travelogue, Krassen op een rots (Amsterdam: Querido, 1970), and more recently, De heren van de thee (Amsterdam: Querido, 1992).

50 Maria Dermoût, Just Yesterday (New York: Simon and Schuster, 1959).

51 A. Alberts, The Islands (Amherst: University of Massachusetts Press, 1983). From 1939 to 1942 Alberts served as a colonial official on Java.

52 E. Breton de Nijs, Faded Portraits (Amherst: University of Massachusetts Press, 1982). E. Breton de Nijs was a pseudonym for Robert Nieuwenhuys.

53 Maria Dermoût, The Ten Thousand Things (New York: Simon and Schuster, 1955).

54 This literary tradition was formally canonized with the publication of Robert Nieuwenhuys, OostIndische Spiegel, Wat Nederlandse schrijvers en dichters over Indonesië habben geschreven, vanaf de eerste jaren der compagnie tot op heden (Amsterdam: Querido, 1972); see also the abridged translation, Robert Nieuwenhuys, Mirror of the Indies: A History of Dutch Colonial Literature (Amherst: University of Mass. Press, 1982). A more theoretically rich treatment of this tradition can be found in E. M. Beekman, Troubled 
24 Andrew Goss

autobiographical mode of narration, the importance of personal memories, and the tension between individual experiences and the colonial government's narrative are all stylistics that tie the books of the 1950s to colonial-era works. This continuity is not surprising; the authors were familiar with the works of Multatuli, Daum, Couperus, and Du Perron. A few features, however, set these post-war texts apart from their precursors. They appeared in rapid succession, but neither the authors nor the texts were in dialogue with each other; all were conceived, written, and published separately and individually. None of them is a critique of colonialism in the tradition of Multatuli or Daum. All these recollections-of youth, early jobs, military service, and so forthworked through the post-colonial trauma of loss by recasting the authors' pasts into elegiac stories.

The narratives listed above stood independent of one another, so that their individual distinctness was more important than their collective likeness. But there were other types of books published at the time that offered precedents for collective colonial remembering. During the early 1950s, military battalions put together memorials honoring their fallen heroes. These books included personal anecdotes, eulogies, and military histories. In many cases they were published to commemorate reunions and had only limited circulation. ${ }^{55}$ In 1956, this genre entered a new phase when an official memorial book was published by and for the Vereeniging van Ambtenaren bij het Binnenlands Bestuur in Nederlands-Indië [Association of Officials from the Territorial Administration of the Netherlands East Indies]. This organization claimed to represent all former members of the colonial territorial bureaucracy. In its commemorative volume, it aimed to honor those officials who gave their lives in World War II by counteracting forgetfulness.

[This book] aims to prevent the quiet vanishing of a corps with honorable traditions, whose members were the pre-eminent bearers of the Pax Neerlandica and made the Netherlands East Indies into an exemplary development. ${ }^{56}$

Significantly, the book contained no single all-encompassing narrative or story. Almost two dozen retired officials, junior and senior, contributed anecdotes, experiences, fragments, memories, and histories. For example, a short sketch entitled, "Memories of my father," was wedged between two articles penned by academic scholars about the origins and development of the corps. The rather eclectic collection of contributions allowed everyone to remember on his own terms. No lengthy personal memoirs could be included.57 This collective memory-work succeeded, however, because an

Pleasures: Dutch Colonial Literature from the East Indies, 1600-1950 (Oxford: Oxford University Press, 1996).

55 J. A. A. van Doorn, De laatste eeuw van Indië, Ontwikkeling en ondergang van een koloniaal project (Amsterdam: Bert Bakker, 1995), p. 310.

56 C. Nooteboom et al., Gedenkenboek van de Vereeniging van Ambtenaren bij het Binnenlands Bestuur in Nederlands-Indië (Utrecht: Oosthoek, 1956), p. VII.

57 This is in contrast to the memoirs of the colonial official M. B. van der Jagt, Memoires van M.B. van der Jagt (Den Haag: Leopolds, 1955). The title page broadcasts the importance of this endeavor; Jagt had been the governor of Surakarta, one of the most prestigious posts in the Indies, and his testament fits into a lengthy tradition of memoirs by high-ranking colonial bureaucrats. The book was compiled in the Netherlands during the closing years of the Nazi occupation and consists mainly of old diary entries, with occasional events receiving further elucidation. The authority for this remembering project, based on old 
institutional framework existed allowing individual experiences and memories to be framed and generalized. In this case, a combination of the particular and the general, bound in a memorial to fallen heroes, brought people together. The front cover of the volume inscribed only with the words "We commemorate ... ,," (Wij Gedenken) ${ }^{58}$ was meant to carry more weight and authority than the cover of any individual's autobiography. The "we" was specific-the colonial officials are remembering-but also general, because it invited the reader to participate by remembering. Furthermore, the range of possibilities of who or what was remembered remained open. This model of colonial remembering was an immediate antecedent for the Indisch journal TongTong, the voice of the Eurasian repatriate.

\section{Tong-Tong: The Only Indisch Magazine in the World}

Individual voices had little chance of breaking the silence about colonialism; they could easily be dismissed as nostalgic and lacking authority. This situation began to change in the course of 1958, when simultaneously with the increased press coverage of returning Dutch citizens, a magazine devoted to Indisch culture and society increased its circulation twenty-fold in the course of a year. This magazine, Tong-Tong, spoke for the plight of the Eurasians and Indisch "browned Netherlanders," those full-blooded Dutch who had come to feel at home in the colony. In the process it launched the debate about assimilation and the colonial past into the Dutch public sphere.

In February 1958, the barely solvent bi-monthly, Onze Brug (Our Bridge), a magazine devoted to building a bridge between the Netherlands and West New Guinea, abruptly changed its name to Tong-Tong. The editor-in-chief, Tjalie Robinson, was a Eurasian writer who had immigrated to the Netherlands in 1954 and had been involved with a series of previous magazines both in Indonesia and Holland. 59 When he altered the format of Onze Brug and changed its name to Tong-Tong, he lost the financial support of a West New Guinea colonization group, but gained the independence to publish stories and editorials to his own liking. The mouthpiece for Eurasian colonization of West New Guinea had found little support amongst the repatriates. With the name change, the magazine was forged into a "tong-tong" - a Malay onomatopoeic word for a signal-drum used either to call a community together to discuss important matters or to warn of impending danger-for the Eurasian

colonial titles and expertise, was the conservative colonial aristocracy. Undoubtedly a market of interested readers, seeking to overcome the loss of prestige associated with the transfer of sovereignty, existed for his book, but the vast majority of the Dutch public could not be brought to remember by any gesturing back to the noble and magnanimous colonial bureaucracy.

58 This phrase could also mean "We remember ..."

${ }^{59}$ Tjalie Robinson's sometime pen name was Vincent Mahieu. The biographical material in English about Tjalie is sparse, and is usually supplemental to a literary treatment of his fiction. For the best biographical background see Winniefred Anthonio, "Tjalie Robinson." See also, Beekman, Troubled Pleasures, pp. 510536; for a taste of his fiction, see Vincent Mahieu, "Vivere Pericolosamente," trans. Anthonio Winifriedo, Indonesia 52 (October 1991): 105-117, and Vincent Mahieu, The Hunt for the Heart: Selected Tales from the Dutch East Indies, tran. Margaret Alibasah (New York: Oxford University Press, 1995). Although the material about Tjalie is more varied in Dutch, it is almost exclusively limited to reprints of his fiction. For his collected fiction, but not any of his journalism, see Vincent Mahieu, Verzameld Werk (Amsterdam: Querido, 1992). 
repatriates in the Netherlands. Describing the new direction he envisioned for the magazine, Tjalie Robinson wrote,

And now our magazine is called "Tong-Tong," a name that cautions preparedness and watchfulness. The word "our" is gone. We do not want and cannot afford to form a separate group in Dutch society. We must instead strive to inform a broad audience far outside of our characteristic circle. We need to attract the entire Dutch public into our sphere of interest and in this magazine do what we do everywhere, in private circles, in restaurant terraces, or in the tram: tell other people who we are and what we can do. Only then can the Indisch group in the Netherlands (a quarter million souls!) become a positive, useful and constructive element of the Dutch people. ${ }^{60}$

This was no small task for a magazine which, in a country of ten million people, was then reaching, at best, one thousand readers. But after a short three years, Tjalie Robinson's ingenuity and flexibility had made it possible to debate moments of the colonial past in a wide public sphere.

The early issues of Tong-Tong in 1958 contained a mere four pages of text; almost three years later, the special Christmas issue of 1960 had thirty-two. Circulation peaked at that time with just over ten thousand subscribers. ${ }^{61} \mathrm{~A}$ number of other forms and changes of content and format also took place during those early years. Most important, the inclusion of photographs, especially group photographs, increased dramatically during this period and came to be used a strategy for drawing diverse elements of the Indisch community together. Aiming to achieve his goal of ensuring a productive future for the neglected citizens of the Netherlands' ex-colony, Tjalie Robinson quickly widened his network of activities to reach beyond mere writing. Rallies, meetings, festivals, banquets, and exhibitions organized through Tong-Tong brought long-lost friends, schoolmates, and families into contact once again. ${ }^{62}$ By soliciting letters, stories, photographs, and anything else from his readers, Tjalie Robinson fostered the emergence of a community which had an active stake in the building of a past and a future.

One stance of the magazine and its editor changed very little during those yearsthe conviction that an accurate history of the Eurasian community needed to be written. On the front page of the March 15, 1958 issue, Tjalie Robinson printed an editorial of his own which discussed De repatrieering uit Indonesië. His criticism of the report on repatriation was subdued; he stressed the accuracy and usefulness of its details before challenging the report's description of the origins of the Indo:

The report is about the origins of the Indo. The report localizes these origins at the end of the previous century, when large contingents of young Dutch in lowly

60 Tjalie Robinson, "Naamsverandering," Tong-Tong 2,14 (March 15, 1958): 2.

61 Anthonio, "Tjalie Robinson," p. 113.

62 For example, Robinson initiated the annual pasar malam, or night carnival, in The Hague in 1959. The yearly pasar malam is now attended by more than 100,000 people. For a description of the 1961 pasar malam, see Anthonio, "Tjalie Robinson," pp. 1-5. 
positions, office and military personnel, came to Indië, married-not legally-and thus formed a mixed-blood community. ${ }^{63}$

Using the evidence of the old Portuguese family names many Indos carried and matriarchal kinship relations within Eurasian communities, he argued that the Indos sprang from an ancient mestizo culture going back all the way to the beginning of the European involvement in Asia. He chided the authors of the report for failing to acknowledge that Indo culture was centuries old and not merely a façade laid over a Dutch foundation. Had they been more careful with their history, their optimistic forecasts of rapid future assimilation might have been tempered. Furthermore, Robinson pointed out that the findings of deficient spiritual independence and awareness amongst the Indos were far from the truth. ${ }^{64}$ This article established the outlines for future debates about assimilation, integration, and absorption that would continue to surface in Tong-Tong. Tjalie Robinson and his supporters wanted to find a productive place for the Indisch community in Dutch society, and they welcomed the efforts by the sociological institutes to help achieve that goal. But it was the terms of that integration-which culture would budge and by how much? - that constituted a crucial issue for Robinson. He and his Tong-Tong readers insisted that their past heritage could never be forgotten, and that it would and should shape the future of the Netherlands.

Almost everyone involved with repatriate issues realized the complexity of the term "assimilation." Many sociologists resolved the semantic problem by offering an exact definition of "assimilation" and all related terms, such as "integration" and "absorption." Tjalie Robinson also understood the fluidity of the word "assimilation," but he continued to use it on his own terms. In his view, total assimilation of the Indisch people into Dutch society meant three things. First, assimilation would need to happen at the group level, not on an individual basis. Assimilation of the Indisch Dutch would not happen if individuals tried to adapt to the ways of the Dutch; they had to speak and act as members of a coherent and self-aware community. Second, after the full self-awareness of the Indisch people had been realized, assimilation could only succeed if the community then promulgated its own culture. Artists had to come forward to create and sustain a developing Indisch culture. Finally, the Indisch Dutch had to learn to become active in the public sphere. Life in the Netherlands East Indies, a country ruled autocratically by a colonial bureaucracy, had never taught citizens to vote or take on other public duties associated with European democracies. For Robinson, adaptation to democratic values and responsibilities did not threaten the Indisch cultural heritage, but was a necessary survival skill for the community, because "regular exchanges of opinion about politics, economy, culture, etc. are essential for existence in European life." 65 He encouraged his readers to participate in politics by regularly debating the pertinent public issues of the day. But, at the same time, he intended to keep such discussions out of Tong-Tong. Repeatedly he stated that his magazine was not political and would not support any political party's ideology. Choosing a political party was an individual's private right and a duty that all Indisch Dutch needed to pursue actively-but on their own. If the Indisch Dutch could follow

63 Tjalie Robinson, "Lijvig rapport over de integratie," Tong-Tong 2,14 (March 15, 1958 ): 1.

$64 \mathrm{Ibid}$.

65 Tjalie Robinson, "Over Politiek," Tong-Tong 2,19 (May 30, 1958): 1. 
these three principles-collective action, cultural production, and active citizenshipsuccessful assimilation could be accomplished. ${ }^{66}$

Tjalie Robinson was keenly aware that if his new magazine reached a sufficiently broad segment of the Dutch public, it could pose a direct challenge to Dutch pillarization, since widely circulated magazines rarely won their readership and built influence outside the dominant political system:

Yes, we are really an independent magazine. Perhaps the only independent magazine in the Netherlands. We stand without direct or indirect aid from political parties or religious orders in the nationally pillarized society. ${ }^{67}$

This independence from conventional Dutch political and religious affiliation allowed the Indisch to pursue cultural remembrance on their own terms. Tong-Tong was meant to shape a politicized, but not a political, community.

A first glance at Tjalie Robinson's ideas about assimilation seems to suggest that he was attempting to build his own pillar in the confessional political system of the Netherlands. After all, he was committed to building an active community with a different, sometimes antithetical, weltanschauung from the majority of the Dutch. His leadership of a magazine was similar to the roles of political leaders of the Catholic or Communist parties who also edited major newspapers. If the Indisch community had been large enough, say more than one million, perhaps Tjalie Robinson would have tried to build a political party in the dominant confessional system. But because of the small size of the Indisch community-which numbered at most 300,000 people-this strategy was doomed to failure or at least insignificance. Even if all the Indisch rallied to Tjalie's side, no serious political party could be sustained. But even while eschewing party politics, he started to form a politicized community challenging the tenets of Dutch society and culture of the 1950s. Most importantly, he made a public space for discussing the history of colonial society. Tong-Tong, the "signal-system for everyone: white and brown, Christian, Islamic, rich and poor, important and unknown," 68 announced and celebrated the numerous historical connections between the metropole and the colony, by printing letters, reminiscences, and photographs of and from anyone who had once felt attached to the colony. The Indisch community, diverse and far-reaching, was to be built from the bottom-up by widely circulating a shared colonial past.

\section{Photographs and Community}

The front page of the March 15, 1958 issue of Tong-Tong boldly proclaimed that all subscribers were active co-workers in the magazine. After all, Tong-Tong printed recipes for Pèpèsan Mackerel, diaries of jungle expeditions in New Guinea, songs sung

66 Tjalie Robinson set out his ideas about assimilation repeatedly, but see especially his, "Is Het Zo?," Onze Brug 2,11 (January 1, 1958): 3; Robinson, "Over Politiek"; Tjalie Robinson, "Overal Integratie," Tong-Tong 3,21 (May 15, 1959): 4.

67 Tjalie Robinson, "Onafhankelijk," Tong-Tong 3,7 (October 15, 1958): 1; at that time, almost all Dutch newspapers were connected to a political party. See Arend Lijphart, The Trauma of Decolonization, p. 159.

68 Tjalie Robinson, “Geen orgaan, geen leden," Tong-Tong 3,1 (July 15, 1958): 2. 
by colonial soldiers, anecdotes about contemporary ill-fated meetings in trams, jokes written in Petjo, ${ }^{69}$ and any and all contributions that demonstrated the unique experience of the people who had lived in the Dutch East Indies. Moreover, Tjalie Robinson made free use of established techniques and strategies for remembering the Indiës. The July 30, 1958 issue included a reprint from the 1956 official colonial memorial, "We Commemorate . . , "70 and the Christmas issue of 1958, flaunted as the "First Anthology of Indisch Literature ever," featured stories by writers such as Robert Nieuwenhuys, Maria Dermoût, and Johan Fabricius. ${ }^{71}$ Robinson was willing to print anything that would grab the attention of the nation; he often reprinted short stories and commemorative anecdotes from other publications, and even recycled highly successful articles from earlier issues of Tong-Tong. Tong-Tong's most important legacy, however, was an original idea by its creator: the massive reprinting of old colonial photographs.

In the early issues of 1958 , small photos were occasionally printed alongside biographies of colonial characters. The photos might convey the physical figure of characters and their clothes or some of the daily trappings of colonial life. But they were always incidental and supplementary, and would have suggested little standing alone. The utility of photos was great altered when, in the April 10, 1958 issue of Tong-Tong, Robinson printed a full-sized photo from 1910 of his parents just after they were married. In a text, printed in italics and intended as a caption, Tjalie wrote various desultory reminiscences of his parents and their lower-class existence in the Indies. In this way the photo is made to provoke the reader into thinking not just about Tjalie Robinson's parents, but all the parents who once lived in colonial Java. This metonymic remembering is realized by the associated caption thus:

And will we forget these fathers and mothers? How can we continue in our Godgiven land, if we do not, as the Bible says, honor our father and mother? May our readers never be ashamed of their past and do their best to do the justice to our history that it deserves. ${ }^{72}$

This photograph, dug out of Robinson's personal album and printed for all to see, was the prelude to a massive public sharing of private family photographs. On the first page of the next issue Robinson requested readers to send in pictures. Any picture from the past would do,

from any time, as long as the atmosphere is brought into focus. For example: a school photo (not too small!), a photo at home or at a picnic, barbers, streethawkers, or becak drivers; typical street theater at a market, or whatever. Very old family-photos are also welcome, in short, any image which makes the reader cry out: "Oh right!!"73

\footnotetext{
69 Petjo was a language used among Eurasians, and originated in urban Batavia. Grammatically Petjo was Malay, but it was interspersed with Dutch, English, Javanese, and Sundanese words.

70 L. A. L. Kortman, "Trouwe Samsoe," Tong-Tong 3,2 (July 30, 1958): 3. Reprinted from Nooteboom, Gedenkenboek, pp. 221-223.

71 "Ons Kerstnummer," Tong-Tong 3,9 (November 15, 1958): 1.

72 Tjalie Robinson, "Vijftig Jaar Geleden," Tong-Tong 2,16 (April 10, 1958): 3.

73 "Wie Stuurt Foto's?," Tong-Tong 2,17 (April 30, 1958): 1.
} 
Within a very short time, photos, coming in from far and wide, became the primary discursive tools for demonstrating the power of the past over the present.

By mid-1958, any single issue of Tong-Tong had a large photograph on every other page. Sometimes the photos stimulated a story: a picture of freshly killed tiger launches a vivid tale of tiger hunting, and depictions of railway stations in "the Preanger" (Priangan) led to a description of traveling between Bandung and Batavia by train. Photos of the contemporary Netherlands became more prevalent at the same time; group-photos taken at meetings and cabaret evenings were reproduced with a short narrative of the proceedings. But the most effective and popular photos were always old pictures of unidentified places and, especially, of almost forgotten people. For example, the October 15, 1958 issue printed a pre-war photo of the sixteen members of a Batavia shooting club. Only one member was positively identified. A month later, the identical photo was reproduced, with all sixteen members' names written underneath. A steady stream of letters from all over the Netherlands had forestalled oblivion. In a postscript, Tjalie Robinson noted, "This is proof that a complete historical reconstruction of overseas Dutch life is possible if everyone participates."74 The photos made it possible for the Indisch Dutch not just passively and privately to contemplate their rich heritage, but to participate publicly in shaping a complete picture of the past.

By the middle of 1959 , photographs had become the most important genre in which Tong-Tong started rebuilding a colonial past. Activities involving photos started to become more involved and sophisticated. Hein Buitenweg and the author Robert Nieuwenhuys made separate requests for quality pictures to be sent to them for use in an exhibit and a book, respectively. ${ }^{75}$ At that time, when the editor of Tong-Tong wrote soliciting more material, he mentioned photographs first, thus indicating their importance: "Send your photo or article now!"76 The popularity of colonial photographs now sparked interest well outside of the regular Tong-Tong circle, and in 1960 and 1961 three photography books, with almost five hundred photographs between them, appeared. ${ }^{77}$ These photography books, which stemmed directly from the photographic collecting efforts of Tong-Tong, ${ }^{78}$ commemorated a collective past for the whole Dutch nation, in a process similar to the effect family photo albums can have on family members. Annette Kuhn, in her book Family Secrets, describes the making of a family photo album as follows:

74 Tong-Tong 3,7 (October 15, 1958): 6; Tong-Tong 3,9 (November 15, 1958): 7. Robinson's emphasis.

75 Hein Buitenweg, "Te Organiseren: foto-tentoonstelling 'Uit Tempo Doeloe,'” Tong-Tong 5,5 (September 15, 1960); E. Breton de Nijs, "Oproep voor Indische Foto's," Tong-Tong 4,22 (June 15, 1960 ): 7.

76 “Lezers in het Buitenland," Tong-Tong 5,3 (August 15, 1960): 2.

77 Hein Buitenweg, Op Java Staat een Huis (Den Haag: Servire, 1960); Hein Buitenweg and Willem Krols, Wat Wij in ons Hart Sloten (Den Haag: Servire, 1961); E. Breton de Nijs (Robert Nieuwenhuys), Tempo Doeloe: Fotografische documenten uit het oude Indië 1870-1914 (Amsterdam: Querido, 1961). This last publication, on page 125, includes a reprint of Tjalie Robinson's photo of his parents originally printed in Tong-Tong 2,16 (April 10, 1958).

78 Buitenweg and Krols, Wat Wij in ons Hart Sloten, introduces the purpose of the book with a quote from Tong-Tong, "Only the memories, brought to life through the photos and souvenirs, shall stay with me, to be given to my small boy, who shall perhaps never get to know the land where he was born, so that he can learn that everything that is important to this mother came from there." 
[A] child's making of a family album was an expression of, and an attempt to come to terms with, fears and desires; to deal with a knowledge that could not be spoken. These silences, these repressions, are written into the album, into the process of its making, and into actual photographs.... Solving the puzzle and acknowledging in the present the effects in the past of a disturbance in the family must be the necessary conditions of a retelling of a family story in its desired "proper" order. As clues are scrutinized and pieces fitted together, a coherent story starts to emerge from the seeming contingency and chaos of a past hinted at by these fragments-a photograph, a photograph album, some memories. A coherent story not only absorbs the listener, but-being a moment in the production of self-satisfies the teller as well, for the moment at least. ${ }^{79}$

The creation of such a family photo album corresponds to Tjalie Robinson's publishing of old colonial photographs, many in fact taken from family photo albums. ${ }^{80}$ A solid representation of colonial society, written by the lost children of the Dutch, started to emerge from Tong-Tong and absorbed the nation with a new narrative. This narrative, unlike the ones proposed by Geyl and Romein, did not rely on the traditional logic and evidence of historians. Rather, it used photographs to evoke "a coherent story . . from the seeming contingency and chaos of a past hinted by these fragments." After a decade of silence about Dutch colonial society, the pioneering use of colonial photographs allowed the nation's history and heritage to be written by a new set of citizens.

By 1959, Tjalie Robinson had accomplished his first goal: ensuring Tong-Tong's financial and structural stability. Enough subscribers, enough contributors, and enough staff finally came together, and the magazine started to run efficiently. At that same time, Robinson himself started to gain attention in the national press as both a public figure and an accomplished writer. Magazines featured him as the hardworking genius who ran Tong-Tong, 81 and in 1959, he was awarded the prestigious Prose Prize from the City of Amsterdam for a set of short stories collected in the volume Tjies. In the same year, the CCKP, moving away from publications entirely authored by national experts, published an anthology of essays and stories about the repatriation. This book, entitled Kinderen van ons Eigen Volk (Children of Our Own People), interspersed stories of repatriates, including Tjalie Robinson, with more conventional sociological articles. ${ }^{82}$ Although "Children" remains in the title, the children no longer need silencing and education, but are starting to speak for themselves.

By the time Kinderen van ons Eigen Volk appeared, the Eurasians and other repatriates were almost full members of the Dutch nation. The Dutch public now acknowledged and respected what the Tong-Tong community insisted on: Indisch culture and history should have some place in post-war Netherlands. By the beginning

79 Annette Kuhn, Family Secrets (London: Verso, 1995), p. 19.

80 Robert Nieuwenhuys's initial interest in photographs was driven by his unsuccessful search for a photograph of his childhood babu, or nursemaid. See de Nijs, Tempo Doeloe, backcover.

81 See for example Robinson's own summary of the interview published in the magazine Vrij Nederland. Tjalie Robinson, "Opbouwende Voorlichting," Tong-Tong 3,19 (April 15, 1959): 1.

82 CCKP, Kinderen van ons Eigen Volk ('s-Gravenhage: Stockum, 1959). J. H. Kraak, the principal researcher and writer of De repatrieering uit Indonesië, wrote the lead-off essay, and Tjalie Robinson's contribution was the first short story. 
of the 1960s, a certain equilibrium was reached in which the repatriates accepted a Dutch middle-class lifestyle, while the Dutch recognized the repatriates' Indisch heritage. ${ }^{83}$ But Robinson wished for much more. His dream of writing colonial history was always tied to reviving the colonial atmosphere in the Netherlands. While he shared the desire to write about the colonial past with many segments of the Dutch public, his dream of using that past to recreate a colonial lifestyle was shared only by a small minority of older Eurasians.

\section{Assimilation with Dialogue}

When, in early 1958, the sociologists finally presented the results of their study on repatriates' adjustment to the Netherlands, their results were already out of date. They were visibly embarrassed by their inability to incorporate the events of the last two months into their analysis. At a press conference on February 16, 1958, J. P. Kruijt, the important pillarization scholar, alongside the chief of the CCKP, J. Moora, and the main rapporteur, J. H. Kraak, stressed the need for an emotional understanding of the Eurasians, not their forcible integration. The sociologists defended their report as being a catalyst for a better understanding of the Eurasians, even if most of the data stemmed from late 1955 and never posed the problem of how to win such understanding from the Dutch. During the discussion following the report's presentation, suggestions were made for writing a second report, this one measuring the reactions of the Dutch public to the repatriates. Successful integration now seemed to mean dialogue; the analytical frame of the report-the belief that pillarization would ease the repatriates into Dutch society-had become hard to defend. Instead mutual understanding was called for. At the end of the press confidence, Tjalie Robinson was given the opportunity to contribute brief remarks supporting the repatriates. ${ }^{84} \mathrm{~A}$ year earlier, his speech would have been perceived by the sociologists as unnecessary. But by February of 1958, a Eurasian voice in the Dutch nation was considered essential.

At the height of Tjalie Robinson's influence in 1959, he confidently railed against attempts to cut the Indisch culture out of the Dutch nation. "People say that it is different with Indonesia. Because it is lower; because it has 'passed.' But it is NEVER past. However old the Netherlands becomes, in her history, Indisch history will leave

83 This is in sharp contrast to the experience of the 4,500 Ambonese-ex-colonial soldiers-and their families who came to the Netherlands in 1950 and 1951. Initially these soldiers and their families, as well as the Dutch authorities, believed they would return to Ambon within a few years. They were consequently housed in makeshift barracks, not infrequently on the grounds of former Nazi concentration camps. Neither the soldiers nor their families were integrated or assimilated into Dutch society in any comprehensive way. The children of the soldiers staged a series of violent hijackings between 1970 and 1978 in which they demanded their own homeland in Ambon. The classic account is Tessel Pollman and Juan Seleky, Istoriistori Maluku--Het verhaal van de Molukkers (Amsterdam: Arbeiderspers, 1979). For an extensive analysis of the Ambonese in post-war Holland, see Dieter Bartels, Ambon is op Schiphol: Socialisatie,

Identiteitsontwikkeling en emancipatie by Molukkers in Nederland (Leiden: Centrum voor onderzoek van Maatschappelijke Tegenstellingen, 1990); for a brief overview in English, see Henk Smeets, Molukkers in the Netherlands (Utrecht: Moluks Historisch Museum, 1992).

84 "De integratie van de gerepatrieerden, 'Menselijke interesse is allereerst nodig,' Lang verwacht rapport verschenen," Nieuwe Rotterdamse Courant, February 18, 1958. 
an indelible mark." 85 Only half of this prophecy came true. The indelible mark of Indisch history is evidenced by the exponential growth of academic monographs, popular histories, and cultural tourist tours to Indonesia. But of course, Robinson's other hope, that Indonesian life and culture could be a significant part of the Netherlands' future as well as its past, was impossible. The stories, photographs, and histories in Tong-Tong had the chance of awakening a national memory, not of altering the political future of the Netherlands. In order for the Eurasians to live in the Netherlands, they would have to undergo a long process of socialization. Before 1958, the state's sociologists felt that assimilation could only happen via pillarization. But this unilateral conception gave way to a more subtle approach by which the Dutch public met the Eurasian repatriates with dialogue and understanding.

This change allayed most of the concerns of both the government and the repatriates. But Tjalie Robinson was not satisfied. He felt that the Dutch press continued to report unfairly on the status of repatriates and, by extension, on himself. ${ }^{86}$ His magazine's subscription and immediate influence seemed to have reached a ceiling of around fifty thousand people. His grassroots operations failed to achieve the political effect he desired. Therefore, in 1961 he emigrated to southern California where he hoped for more success with the large community of Eurasians that had formed there in the 1950s. ${ }^{87}$

The initial space created by the repatriation emergency in late 1957 and early 1958 was quickly exploited by Tjalie Robinson and his bi-monthly magazine. But the trick Robinson learned about ethnic community building-that photographs could excite an interest in a shared past-did not lead to the resurrection of colonial society in Holland. By reminding readers that colonial society could be remembered without pain, these photographs made a place for the Indies in post-war Holland. But while Tong-Tong transformed the ways that the Indies could be remembered, it could not dictate the specific paths memory would follow. The history of the Indies became bracketed inside the main narrative of the Dutch nation, but the meaning assigned to this colonial history was not what Robinson had hoped for.

By the middle of the 1960s concern with the plight of the Eurasians had shifted from the national public sphere to various niche communities. ${ }^{88}$ The repatriates ceased to be widely perceived as a social problem, and the interest in Indisch history and culture subsided. In 1971, the sociologist H. G. Surie wrote about Tong-Tong,

85 Tjalie Robinson, "Indisch," Tong-Tong 3,24 (June 30, 1959): 7.

86 Tjalie Robinson, "Daar en Hier," Tong-Tong 5,7 (October 15, 1960 ): 1.

87 See Anthonio, "Tjalie Robinson," chapter 3, for the best biographical information. He took a publicity tour of the Caribbean and the US in 1961, which convinced him of the most appropriate environs for his energies. He lived in Whittier, Southern Califormia, for five years, but was forced to return to the Netherlands in 1966 because the journal Tong-Tong was losing readership. He died eight years later after suffering from numerous heart attacks. For a recollection of Tjalie in California, see Marguerite Schenkhuizen, Memoirs of an Indo Woman: Twentieth-Century Life in the East Indies and Abroad (Athens, $\mathrm{OH}$ : Ohio University Center for International Studies, 1993), pp. 232-233.

88 By that time Tong-Tong's subscription had shrunk significantly. Although Tong-Tong struggled during the late 1960s and early 1970s, and vanished for four years after Tjalie Robinson's death in 1974, it reemerged as Moesson in 1978 and is still published once a month. For a brief overview of Moesson's current activities, see its web page, <URL: http://www.moesson.org>. 
34 Andrew Goss

Apparently it is a magazine for Indos, who have given themselves an Indoidentity, and simultaneously realized that they are irrevocably Dutch. All the elements of the Indo-ideology are found in Tong-Tong. Primarily oriented towards the colonial past, they do not discuss any actual problems. News is also absent, and the opinion articles are preoccupied with Indo-culture. The lack of Dutch interest in the Indisch group is disparaged. Especially notable is that for the readers (and the editorial staff) no real assimilation problems appear to exist. They are in any case not discussed... . [But] Tong-Tong has done useful work as a safety valve. I am of the opinion that Tong-Tong was a not-to-beunderestimated positive factor in the assimilation process, and for many older Indos still is. The youths do not need Tong-Tong. The problems of Tong-Tong and the elders are not theirs. ${ }^{89}$

Although Tong-Tong continued even without Tjalie Robinson, its circulation was limited, and it became more and more a vehicle for conservative ideas. After 1960, and after the topic of assimilation ceased to be a lighting rod, Tong-Tong was left hobbled with its futile political program, which advocated a return to the colonial past. But while the politics of Tong-Tong had a minor effect on the nation, the magazine's contribution to the debate about the meaning of colonialism in Dutch history was quite significant.

\section{Tempo Doeloe and the Bracketing of Colonial History}

Since 1960, the history of colonial society in the Netherlands East Indies has been a component of Dutch national history and identity. This colonial history has not, however, entered the main narrative of the nation as an integral epoch or watershed, but rather as something put in brackets. The actual chaos of colonial society has been structured into a coherent picture, and by extension a coherent history. The photographs of Eurasians in Tong-Tong demonstrated how collective remembering could become history, but it was not until 1961, when Robert Nieuwenhuys published Tempo Doeloe: Fotografische documenten uit het oude Indië 1870-1914 (Tempo Doeloe: Photographic documents from the former Indies 1870-1914), that photographs became the historical link between post-war Dutch culture and the Indies. Nieuwenhuys started his book by defining tempo doeloe as "the age that we did not live through, but with which relations have not yet been broken. It is no longer the present; it has become the past, but not yet history." 90 Nieuwenhuys shared with Robinson the desire to learn about the colonial past via photographs, but his scope was much larger. Everything made it into Nieuwenhuys's book: dogs, explorers, hangings, the governor-general's palace, trees, and servants. And finally Nieuwenhuys made a distinction Tjalie Robinson did not: tempo doeloe was a period which could not be revived or revisited.

If the photographs and the display formats in Tong-Tong and Tempo Doeloe are generally similar, their underlying ideology could not be more different. As we have

${ }^{89}$ H. G. Surie, "De gerepatrieerden," p. 104. This is a summary based on H. G. Surie and R. J. Kuiper, "De Indo en Tong-Tong. Een onderzoek naar de Indo-European vroeger en nu" (Universiteit van Amsterdam, doctoraalscriptie, 1967).

90 E. Breton de Nijs [Robert Nieuwenhuys], Tempo Doeloe, p. 1. 
seen, the photographs in Tong-Tong represented people, especially Eurasians, who could be recognized and named. Tjalie Robinson, in his attempt to launch a social movement, anchored photographs in the historical past with comments on individuals' biographies and specific locations. Robinson's photos tried to lend solidity to a denied past, which, in turn, could recreate Eurasian society. But Robert Nieuwenhuys's project was quite different. He was interested in constructing a photo album about the totality of Dutch colonialism, not just the small Eurasian minority. The Tempo Doeloe photos are anonymous and metaphorical, and the captions strive to explain the complexities of the development of Dutch colonial society between 1870 and 1914 . Here is a typical caption:

Some planters in the interior with their servants and hunting dogs; a patriarchal community, which does not lack the nyai. She stands (next to her master [heer]); the other women are kneeling. Also the care taken in her appearance and her clothing set her apart from the others. This photo is from 1901 or 1902. Already the white blouse [kabaai] was characteristic of the nyai.91

The people in this photograph are less important than the photograph's ability to create an interpretive framework. The bare minimum of concrete facts-notably the date-is provided, but a reading of colonial patriarchy is the intended message. Throughout the book, Nieuwenhuys taught the art of decoding colonial photographs. Unlike Tong-Tong, which insisted that colonial society should be recreated in the Netherlands, Tempo Doeloe asked the reader to consider colonial society a part of Dutch history, even though Indië was now forever separated from the Netherlands. While Robinson created a space for colonial history-his indelible brackets are the photographs-Nieuwenhuys was the first to fill that space with material of interest to a wider public. ${ }^{92}$

Simultaneously with the publication of Tempo Doeloe, the history of colonial domination resurfaced in national debate with the publication in 1961 of Balans van Beleid (Balance of Policy) - a collection of essays about the colonial Beamtenstaat, a large number of which were written by ex-colonial officials. ${ }^{93}$ The first such systematic study to appear after decolonization, it attempted to place the colonial rule of Indonesia in a wide historical context. In many ways it returned to debates which had earlier appeared in the "trade journals" of the ex-colonial bureaucrats. But there was one difference: the essays were purely historical and had no policy implications. They all attempted to weigh historically the benefits and costs of long-gone colonial policies in the Indies. The book is unlike Tempo Doeloe in its lack of photographs and witty captions, but resembles it in its bracketing of colonial history. ${ }^{94}$ Both texts largely

\footnotetext{
91 Ibid., p. 88.

92 Tempo Doeloe was instantly a classic, and has remained a versatile source book for photographs of colonial Indonesia. For an early example of its use in the United States, see the two photos reproduced in Eugene Rachlis, The Low Countries (New York: Time Incorporated, 1963), pp. 38, 45.

93 Henri Baudet and I. J. Brugmans, eds., Balans van Beleid. Terugblik op de laatste eeuw van NederlandschIndië (Assen: van Gorcum, 1961).

94 This approach was not without its critics. Harry Benda once said that the spirit of this book was characterized by "the unshakable belief in Dutch superiority, from an unperturbed certitude in the rightness—and inevitable gradualness—of the Dutch civilizing mission in Indonesia." Harry J. Benda, "The
} 
occlude Indonesians and Eurasians and focus on the Dutch. In this way the history is the history of Dutch colonialism in Asia-a historical aside-which could not be woven into any grand narrative of Dutch history, but had a place at its margins.

How has the history of the Netherlands East Indies affected the post-war historiography of the Netherlands? Before 1960, its influence was only oblique. During the 1950s, the history of colonialism was not forgotten, but certainly was institutionally ignored. For historians and other scholars, such as the pillarization sociologists, the Netherlands East Indies was an embarrassment and of little relevance to building a new Dutch culture. Only after 1958, and after the government and press took a more sympathetic view of the Eurasian repatriates, could colonial history be discussed in the public sphere. Tong-Tong, with its emphasis on shared memories of Eurasian repatriates, created a forum for discussing at least some aspects of the colonial past. And by removing the political immediacy of the colonial period, Robert Nieuwenhuys made it possible for colonial history, especially the history of tempo doeloe, to start being written by non-Eurasians. History and memory turned out to be good allies. By the early 1970s, colonial history had become a significant part of academic historiography. Yet this historiography has, like the histories in Tong-Tong and Tempo Doeloe, remained bracketed inside the larger story of Dutch history. For example, in J. J. Woltjer's recent magisterial social history of twentieth-century Netherlands, the history of the colony, from the ethical policy to the decolonization of New Guinea, is all covered in one chapter in the middle of the book. ${ }^{95}$ This strange treatment shows us that the meaning of colonial history to Dutch history still remains confused and unclear.

Pattern of Administrative Reforms in the Closing Years of Dutch Rule in Indonesia," Journal of Asian Studies 25,4 (November 1966): 590.

95 Woltjer, Recent Verleden, pp. 165-229. 